\title{
Аналіз тренувальних програм, розроблених з урахуванням будови тіла спортсменів
}

\author{
Удк 612.017.2
}

\section{С. А. Пітенко ${ }^{1}$, О. М. Лисенко}

${ }^{1}$ Київський університет імені Бориса Грінченка, Київ, Україна
${ }^{2}$ Національний університет фізичного виховання і спорту України, Київ, Україна

\begin{abstract}
Резюме. Мета. Розробка та експериментальне обґрунтування ефективності тренувальних програм, створених з урахуванням будови тіла спортсменів. Методи. Було проаналізовано засоби тренувальної роботи спортсменів, які займаються бодибілдингом, за допомогою методів антропометрії та каліперометрії. Визначався тип будови тіла за методом Хіт-Картера. Результати. Нами розроблено та доведено ефективність програм тренувальних занять 3 бодибілдингу з урахуванням будови тіла спортсменів. Після застосування експериментальних програм у спортсменів усіх груп спостерігалося збільшення м'язової тканини, а в ендоморфів - достовірне зниження жирової тканини. Висновки. Дослідження довели, що ефективність тренувального процесу спортсменів, які займаються бодибілдингом, залежить від індивідуальних особливостей будови тіла. Застосовані експериментальні програми тренувальних занять виявилися адекватними для спортсменів з різною будовою тіла. Ключові слова: будова тіла, компоненти тренувальної роботи, бодибілдинг.
\end{abstract}

\begin{abstract}
Резюме. Цель. Разработка и экспериментальное обоснование эффективности тренировочных программ, созданных с учетом типа телосложения спортсменов. Методы. Были проанализированы средства тренировочной работы спортсменов, занимающихся бодибилдингом, с помощью методов антропометрии и калиперометрии. Определялся тип телосложения методом Хит-Картера. Результаты. Доказана эффективность разработаных нами программ тренировочных занятий по бодибилдингу с учетом типа телосложения спортсменов. После применения экспериментальных программ у спортсменов всех групп наблюдалось увеличение мышечной ткани, а у эндоморфов - достоверное снижение жировой ткани. Выводы. Исследования доказали, что эффективность тренировочного процесса спортсменов, занимающихся бодибилдингом, зависит от индивидуальных особенностей типа телосложения. Примененные экспериментальные программы тренировочных занятий оказались адекватными для спортсменов с различным типом телосложения.

Ключевые слова: тип телосложения, компоненты тренировочной работы, бодибилдинг.
\end{abstract}

\begin{abstract}
Objective. Development and experimental substantiation of the effectiveness of training programs developed with account for athletes' body build. Methods. Means of training activity of bodybuilders have been analyzed by methods of anthropometry and caliperometry. The type of body build has been determined by the Hit-Carter method. Results. We have developed and proved the effectiveness of training programs for bodybuilding taking into account the athletes' body build. After application of experimental programs in athletes of all groups there was an increase in muscle tissue, whereas in endomorphs - a significant decrease in adipose tissue. Conclusions. Studies have shown that the effectiveness of the training process of athletes involved in bodybuilding depends on the individual features of the body build. Applied experimental programs of training sessions were adequate for athletes with different body build.
\end{abstract}

Keywords: body build, training activity components, bodybuilding.

Постановка проблеми. Різноманіття спортивних спеціалізацій дозволяє реалізувати кваліфрікованим спортсменам з різною будовою тіла свої морфологічні особливості. Вищі люди прагнуть досягти успіху у видах спорту, що вимагають високого зросту, - таких, як баскетбол чи волейбол, нижчі - у видах спорту, які потребують обертання тіла навколо осі, наприклад гімнастиці. У межах одного виду спорту специфічне положення може диктувати переваги розміру тіла. В ігрових видах спорту більша маса тіла вигідна для гравців лінії захисту. Навпаки, нападаючі гравці прагнуть бути легшими, оскільки це дозволяє їм бігати з більшою швидкістю. Склад тіла має значення у видах спорту, які вимагають переміщення тіла у просторі. У цих випадках надлишкова маса заважає, оскільки вона збільшує навантаження, не сприяючи можливостям 
організму підвищувати зусилля. Більше того, це обумовлює більші метаболічні витрати, які обмежують тривале виконання вправ [1], а також порушує терморегуляцію, що так само $€$ несприятливим чинником.

Специфрічні рекомендації щодо складу тіла для спортсменів варто визначити, однак деякі спортсмени потребують корекції складу тіла та мають не тільки зайву масу тіла, але й перебувають у зоні потенційного ризику для здоров'я, або мають відсоток жирової маси тіла більший ніж $25 \%$ та позиціонуються як тучні [7].

Досягнення й підтримка оптимальної маси тіла важливі для демонстрації високих спортивних результатів. Відповідні розміри, склад і будова тіла мають велике значення для досягнення успіху майже у всіх спортивних дисциплінах [1, 6]. Крім того, вважається, що тучність збільшує ризик захворюваності, оскільки вона пов'язана із серцево-судинними захворюваннями, діабетом та іншими хронічними хворобами $[1,10]$. Надзвичайно низька маса тіла, низький рівень жирової маси, а також швидкі зміни складу тіла можуть бути наслідком або стати причиною хворобливих станів чи травм. Оптимізація складу тіла приводить до підвищення відносних функціональних показників [10], що сприятиме кращій реалізації потенціалу спортсменів в умовах змагальної діяльності.

Розміри, форма і склад тіла багато в чому зумовлені генетично. Це, однак, не означає, що не можна змінити або поліпшити ці компоненти фрізичного профрілю. Якщо розмір і будову тіла можна скоригувати незначно, то склад тіла можна істотно змінити за допомогою дієти й фрізичних вправ. Тренування силової спрямованості дозволяє значно збільшити м'язову масу, а раціональна дієта в поєднанні з інтенсивними фрізичними навантаженнями дають змогу суттєво знизити вміст жиру в організмі. Подібні зміни можуть мати велике значення для досягнення високих спортивних результатів [8].

Морфологічні відмінності між представниками різних видів спорту $є$ наслідком не тільки інтенсивного відбору, а й адаптаційними реакціями, що зумовлені дією специфічних засобів і методів підготовки, характерних для конкретного виду спорту [6].

Для кожного етапу відбору характерні свої методи та критерії. На першому етапі основну роль відіграють генетично детерміновані антропометричні та морфологічні характеристики тих, хто займається, і яким властива незначна мінливість під впливом тренування [5].

Мета роботи: розробка та експериментальне обгрунтування ефективності тренувальних програм, створених з урахуванням будови тіла спортсменів, і перевірка ефективності цих програм на практиці.

Зв'язок роботи 3 науковими планами, темами. Робота виконувалася відповідно до держбюджетної науково-дослідної теми «Технологія індивідуалізації тренувального процесу на основі фрізіологічних критеріїв» (номер держреєстрації 0117U002388) Міністерства освіти і науки України.

Методи та організація досліджень. Ми проаналізували ефективність засобів тренувальної роботи спортсменів, які займаються бодибілдингом, за допомогою методів антропометрії та каліперометрії. Вивчали зміну показників складу тіла, вираженість компонентів будови тіла, величини підшкірно-жирових складок і обхватних розмірів тіла спортсменів до та після застосування програми тренувальних занять.

Всіх спортсменів експериментальної групи було розділено на три групи з урахуванням будови тіла за методом Хіт-Картера [2, 10]: група «A» - ендоморфи, група «Б» - мезоморфи, група «В» - ектоморфи. Також було розроблено програми тренувальних занять 3 бодибілдингу з урахуванням будови тіла спортсменів. Спортсмени контрольної групи тренувалися за програмою на основі загальновизнаних показників тренувальної роботи, без урахування будови тіла. Статистичну обробку результатів проводили з використанням комп'ютерної програми STATISTICA v6.

Результати дослідження та їх обговорення. Оскільки оптимальною кількістю тренувальних занять у тижневому мікроциклі для мезоморфів та ендоморфів $\epsilon$ три заняття, а для ектоморфів - від трьох до п'яти, то для спортсменів усіх груп ми використовували мікроцикли, тривалість яких становила 7 днів з трьома тренувальними заняттями у тижневому мікроциклі. На думку багатьох провідних авторів [3, 4, 6], цей показник тривалості окремого мікроциклу $\epsilon$ найбільш оптимальним i найчастіше застосовується спортсменами.

В експериментальній програмі кількість тренувальних занять у тижневому мікроциклі, що спрямовані на розвиток окремих м'язових груп спортсмена, була наступною (табл. 1): для ендоморфів застосовували програму тренувальних занять, у якій грудні м'язи, м'язи спини та дельтоподібні м'язи навантажували один раз на тиждень, трапецієподібні м'язи, м'язи ніг, рук та живота - три рази на тиждень.

Слід зазначити, що у мезоморфів та ектоморфів в експериментальній програмі м'язи рук навантажували по одному разу на тиждень - двоголовий та триголовий м'язи плеча кожний на окремому 
ТАБЛИЦЯ 1 - Кількість тренувальних занять у тижневому мікроциклі, що спрямовані на розвиток окремих м'язових груп

\begin{tabular}{|l|c|c|c|c|}
\hline \multirow{2}{*}{\multicolumn{1}{|c|}{ М'язи }} & \multicolumn{2}{|c|}{ Експериментальна програма } & Контрольна \\
\cline { 2 - 5 } & $\begin{array}{c}\text { ендо- } \\
\text { морфи }\end{array}$ & $\begin{array}{c}\text { мезо- } \\
\text { морфи }\end{array}$ & $\begin{array}{c}\text { екто- } \\
\text { морфи }\end{array}$ & $\begin{array}{c}\text { програма } \\
\text { Грудей }\end{array}$ \\
Спини & 1 & 1 & 1 & 1 \\
Трапецієподібний & 3 & 1 & 1 & 1 \\
Дельтоподібний & 1 & 1 & 1 & 1 \\
Двоголовий плеча & 3 & 1 & 1 & 1 \\
Триголовий плеча & 3 & 1 & 1 & 1 \\
Живота & 3 & 2 & 1 & 3 \\
Стегна & 3 & 1 & 1 & 1 \\
Гомілки & 3 & 1 & 1 & 1 \\
\hline
\end{tabular}

тренувальному занятті, тоді як в експериментальній програмі для ендоморфів двоголовий та триголовий м'язи плеча зазнавали навантаження на кожному тренувальному занятті. Для мезоморфрів застосовували програму тренувальних занять, у якій всі м'язи, окрім м'язів живота, зазнавали навантаження один раз на тиждень, м'язи живота навантажували двічі на тиждень. У мезоморфів в експериментальній програмі трапецієподібні м'язи навантажували окремо від інших м'язів спини один раз на тиждень разом із дельтоподібними м'язами. Для ектоморфрів застосовували програму тренувальних занять, у якій всі м'язи навантажували один раз на тиждень. М'язи ніг навантажували двічі на тиждень: на одному тренуванні - м'язи стегна, на іншому - м'язи гомілки.

Середня тривалість окремого тренувального заняття в експериментальній програмі для ендоморфів і в контрольній програмі була найбільшою та становила 4579,50 та 3888,33 с відповідно. Середня тривалість окремого тренувального заняття в експериментальній програмі для мезоморфів та ектоморфів була майже вдвічі меншою і складала для мезоморфів 2221,00 с, для ектоморфів - 1704,00 с (рис. 1).

Виходячи з того, що нервова система може підтримувати оптимальний рівень збудження до 30-40 хв, в експериментальних тренувальних програмах пріоритетні групи м'язів для кожної групи спортсменів тренували на початку заняття. Це відповідає основному напрямку в тренуванні та стимулює всі типи м'язових волокон, що, в свою чергу, сприятиме зростанню м'язової маси спортсменів та зниженню жирового прошарку до оптимального рівня.

При цьому тривалість відпочинку між сетами в експериментальній програмі на м'язи живота становила 30 с, на інші групи м'язів - 60 с. У контрольній програмі тривалість відпочинку між сетами в екстремальній програмі на м'язи живота складала 30 с, на інші групи м'язів - 90 с.

Тривалість окремого тренувального заняття в різних програмах встановлювалася за рахунок різних компонентів (див. рис. 1), а саме: тривалість виконання вправ в окремому тренувальному занятті експериментальної програми для ендоморфів майже вдвічі більша, ніж в експериментальній програмі для мезоморфів та контрольній програмі 53,9 та 47,2 \% відповідно, та майже втричі більша, ніж у ектоморфів - 69,1 \%. Тривалість відпочинку в окремому тренувальному занятті в контрольній та експериментальній програмах для ендоморфів не відрізнялась ( $<<0,05)$, та була більша ніж в експериментальній програмі для мезоморфів та ектоморфів, на 52,4 та 60,8 \% відповідно.

Кількість задіяних м'язових груп в окремому тренувальному занятті різниться залежно від будови тіла спортсменів. Так, в експериментальній програмі вона становила: для ендоморфів - 6, для мезоморфів - 3, для ектоморфів - 2-4, у контрольній програмі - 3-4 м'язові групи. Кількість вправ, яка застосовується для навантаження окремої м'язової групи у тренувальному занятті, була наступною: в експериментальній програмі для ендоморфів - 1-5, для мезоморфів - 1-7, для ектоморфів - 1-5, у контрольній програмі - 2-4 вправи.

Порівняльний аналіз тренувальних програм показав (рис. 2), що кількість базових вправ на окрему м'язову групу за одне тренувальне заняття в експериментальній програмі становить: для ендоморфів - 0,94 \pm 0,07, для мезоморфів $1,44 \pm 0,33$, для ектоморфів - 2,50 \pm 0,51, у контрольній програмі - 1,36 \pm 0,33. Кількість ізолюючих вправ на окрему м'язову групу за одне тренувальне заняття в експериментальній програмі

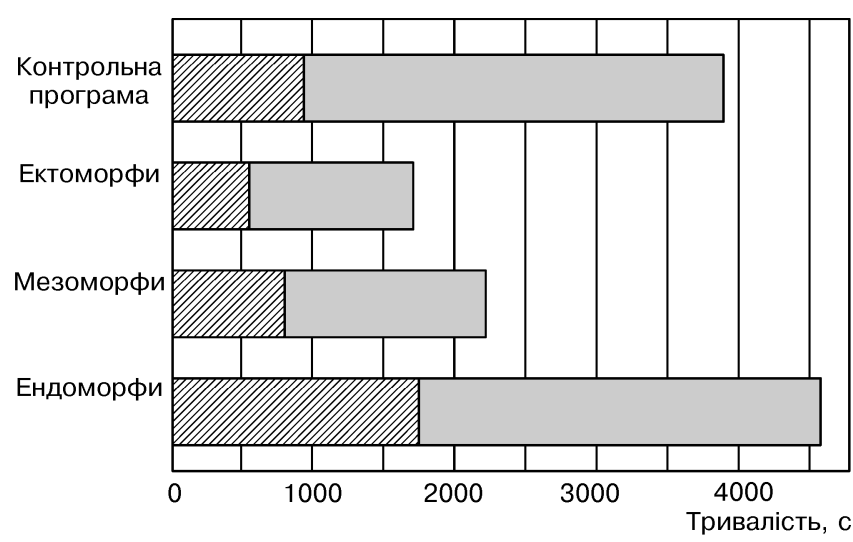

Рисунок 1 - Відмінності між контрольною та експериментальними програмами тренувальних занять, виражена в загальній тривалості виконання вправ (U//) і відпочинку між сетами в окремому тренувальному занятті ( $\square$ ), с 


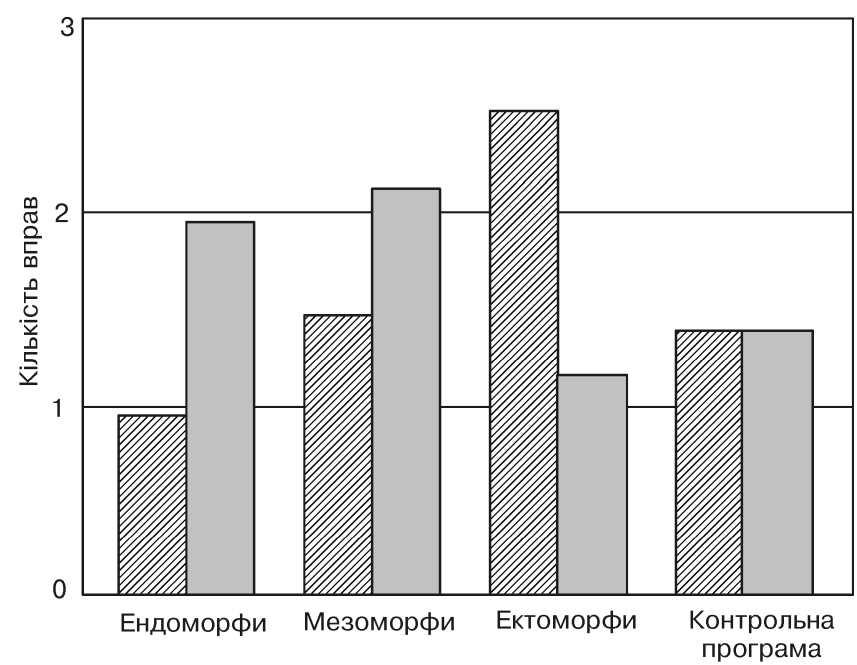

Рисунок 2 - Відмінності між контрольною та експериментальними програмами тренувальних занять, виражена в кількості базових (U//A) та ізолюючих ( $\square$ ) вправ на окрему м'язову групу за одне тренувальне заняття

становить: для ендоморфів - 1,94 $\pm 0,51$, для мезоморфів - 2,11 $\pm 0,45$, для ектоморфів $1,13 \pm 0,33$, у контрольній програмі $-1,36 \pm 0,51$.

При цьому кількість сетів в одній вправі, що використовуються в одному тренувальному занятті, в експериментальній програмі становить: для ендоморфів - 3-6, для мезоморфів - 3-5, для ектоморфів - 3-6, у контрольній програмі - 2-4.

Якщо необхідність зниження маси жирової тканини ендоморфів та збільшення маси м'язової тканини ендоморфів та ектоморфів не викликає

ТАБЛИЦЯ 2 - Критерії оцінки динаміки компонентів складу тіла та вираженості компонентів будови тіла в результаті тренувань

\begin{tabular}{|c|c|c|c|}
\hline Показник & $\begin{array}{l}\text { Ендо- } \\
\text { морфи }\end{array}$ & $\begin{array}{l}\text { Мезо- } \\
\text { морфи }\end{array}$ & $\begin{array}{l}\text { Екто- } \\
\text { морфи }\end{array}$ \\
\hline Маса тіла, кг & $\downarrow$ & $\uparrow$ & $\uparrow$ \\
\hline Активна маса тіла, кг & \multicolumn{3}{|c|}{$\begin{array}{c}\uparrow \text { Здебільшого за рахунок } \\
\text { м'язової тканини }\end{array}$} \\
\hline Маса м'язової тканини, кг & $\uparrow$ & $\uparrow$ & $\uparrow$ \\
\hline Маса жирової тканини, кг & $\downarrow$ & - & - \\
\hline $\begin{array}{l}\text { Середня товщина підшкір- } \\
\text { но-жирових складок, мм }\end{array}$ & $\downarrow$ & - & - \\
\hline $\begin{array}{l}\text { Відносна маса жирової } \\
\text { тканини, \% }\end{array}$ & $\downarrow$ & - & - \\
\hline $\begin{array}{l}\text { Відносна маса м'язової } \\
\text { тканини, \% }\end{array}$ & $\uparrow$ & $\uparrow$ & $\uparrow$ \\
\hline \multicolumn{4}{|c|}{ Вираженість компонентів будови тіла: } \\
\hline ендоморфного & $\downarrow$ & $\downarrow$ & $\downarrow$ \\
\hline мезоморфнного & $\uparrow$ & $\uparrow$ & $\uparrow$ \\
\hline ектоморфнного & $\uparrow$ & $\downarrow$ & $\downarrow$ \\
\hline
\end{tabular}

Примітки: $\uparrow$ - необхідність збільшення показника; $\downarrow$ - необхідність зниження показника; «-» - корекція залежно від індивідуальних особливостей. сумнівів, то корекцію маси жирової тканини ендоморфрів та мезоморфів і збільшення маси м'язової тканини мезоморфів потрібно здійснювати залежно від індивідуальних особливостей спортсменів. Це обумовило необхідність розроблення критеріїв оцінки динаміки компонентів складу тіла в результаті тренувань. Якщо $є$ потреба у наборі м'язової тканини у мезоморфів, критерії оцінки динаміки компонентів складу тіла та вираженості компонентів будови тіла в результаті тренувань виглядатимуть так, як наведено у таблиці 2.

Оскільки зниження жирової тканини в складі тіла ендоморфів потрібно здійснювати швидше, ніж збільшення м'язової тканини, через надмірний прошарок жирової тканини, то в результаті тренувань у ендоморфів мають відбуватися такі зміни: зниження маси тіла за рахунок жирової тканини та збільшення активної маси тіла за рахунок маси м'язової тканини. Позитивним результатом для ендоморфів слід вважати зниження ендоморфного та збільшення мезоморфного та ектоморфного компонентів будови тіла.

У зв'язку з тим що для мезоморфів та ектоморфрів основним завданням тренувань $\epsilon$ збільшення маси м'язової тканини, а для ектоморфів можливе збільшення жирової тканини, то позитивним результатом для мезоморфрів та ектоморфів слід вважати: збільшення маси тіла за рахунок маси м'язової тканини i, можливо, жирової тканини та збільшення активної маси тіла переважно за рахунок маси м'язової тканини. Позитивний результат для мезоморфів та ектоморфів - зниження ендоморфного та ектоморфного та збільшення мезоморфного компонентів будови тіла. Слід зазначити, що, на відміну від ендоморфів, у яких зниження жирової тканини $\epsilon$ основною метою тренування, для мезоморфів та ектоморфів, залежно від індивідуальних особливостей, може існувати необхідність як зниження, так і збільшення жирової тканини.

Результати досліджень довели певну адекватність показників тренувальної роботи контрольної програми тренувальних занять, однак деякі отримані дані експерименту виявилися статистично недостовірними. Так, у ендоморфів (рис. 3) відмічається зниження товщини підшкірно-жирових складок, відносної та абсолютної маси жирової тканини на 5,6 \%, 6,6 та 5,60\% (p<0,05) відповідно та збільшення м'язової маси мезоморсрів на $3,11 \%(p<0,05)$.

I хоча контрольна програма тренувальних занять відповідає основному напрямку в тренуванні для ендоморфів - зниження маси жирової тканини та для мезоморфів - набір м'язової маси, однак незначні та недостовірні зміни інших 


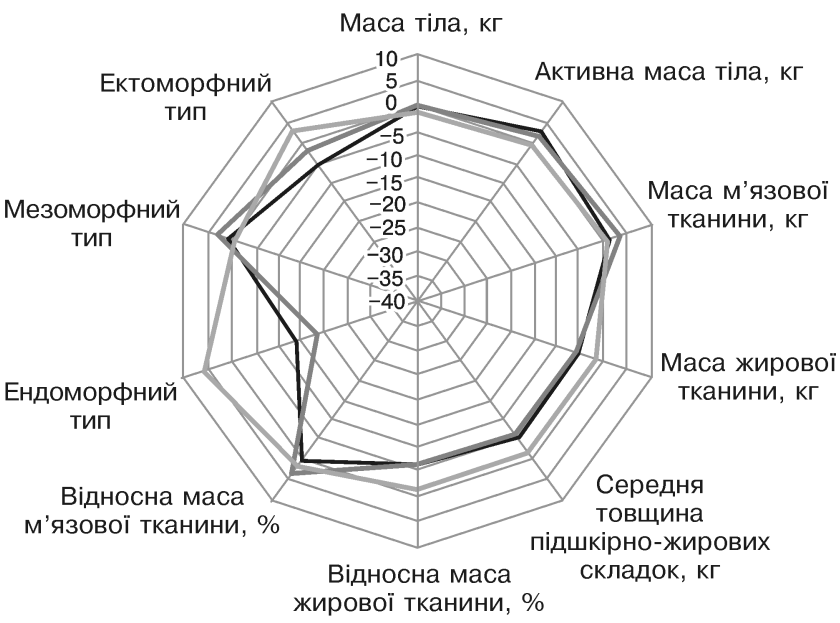

Рисунок 3 - Динаміка антропометричних показників і показників складу тіла за результатами тестування спортсменів контрольної групи $(n=30)$ : - - ендоморфри; —- мезоморфи; —- ектоморфи

показників свідчать про те, що в цілому контрольна програма не була адекватною будові тіла ендоморфів та ектоморфів.

Виконання в експериментальних тренувальних програмах вправ на пріоритетні групи м'язів для кожної групи спортсменів на початку заняття та застосування малих інтервалів відпочинку призвели до позитивних змін обхватних розмірів та зменшення жирового шару у ендоморфів на $26,56 \%(p<0,05)$, мезоморфів - на $13,41 \%$ ( $>>0,05)$, ектоморфів - на 1,09\% ( $>0,05)$.

На думку Уїлмора та Костіла [8], якщо маса спортсмена перевищує верхню межу маси, що рекомендується для даного виду спорту, її зниження не повинно перевищувати 0,5-1 кг на тиждень. При швидшому зниженні втрачається активна маса тіла. У разі досягнення верхньої межі діапазону маси подальше зниження слід проводити під наглядом тренера або лікаря команди. Зниження не має перевищувати 0,5 кг на тиждень, щоб уникнути можливого негативного впливу на м'язову діяльність.

Зниження маси жирової тканини спортсменів усіх груп відбувалося в межах вищезгаданих норм, а саме у спортсменів груп «А», «Б» та «В» на 6,86 кг, 1,70 та на 0,10 кг відповідно за три місяці експерименту. Раціональність змін складу тіла спортсменів також підтверджує достовірне збільшення активної маси тіла та маси м'язової тканини спортсменів усіх груп після застосування експериментальної програми тренувальних занять. Це свідчить про те, що експериментальна програма виявилася адекватною будові тіла спортсменів (рис. 4).

Хоулі та Френкс [9] при корекції складу тіла пропонують розглядати не тільки відсоток жиру



Рисунок 4 - Динаміка антропометричних показників і показників складу тіла за результатами тестування спортсменів експериментальної групи ( $\mathrm{n}=30)$ : - ендоморфи; — - мезоморфи; —— - ектоморфи

в тілі, але й його розподіл. Надлишок жиру в черевній порожнині пов'язаний зі збільшенням ризику серцево-судинних захворювань і підвищеною захворюваністю на цукровий діабет другого типу (інсуліннезалежний). Крім цього, при визначенні вмісту жиру в різних частинах тіла необхідно вимірювати об'єм талії та стегон. Співвідношення між обхватними розмірами талії та стегон, яке перевищує 0,8 у чоловіків, пов'язане з підвищеним ризиком гіпертригліцеридемії, цукрового діабету другого типу, гіперінсулінемії та артеріальної гіпертензії.

У чотирьох спортсменів групи «А» до застосування експериментальної програми тренувальних занять показники відношення об'єму талії до об'єму стегон перебували поза межами норми, що, на думку авторів [9], $\epsilon$ фрактором ризику розвитку серцево-судинних захворювань, гіпертригліцеридемії, цукрового діабету другого типу, гіперінсулінемії та артеріальної гіпертензії. Після застосування експериментальної програми тренувальних занять у спортсменів групи «А» спостерігалось достовірне зменшення відношення об'єму талії до об'єму стегон на 1,19\% (p<0,05), що також слід розглядати як позитивні зміни.

Це $є$ підтвердженням того, що експериментальна програма відповідає основному напрямку в тренуванні для ендоморфів - прискорення метаболізму, і призвела до достовірного зниження маси жирової тканини, товщини підшкірно-жирових складок, відносної маси жирової тканини, а також до збільшення активної маси тіла, м'язової маси та відносної маси м'язової тканини. Достовірні зміни свідчать про те, що експериментальна програма виявилася адекватною будові тіла даної групи спортсменів. 
Аналіз одержаних результатів підтверджує те, що застосована експериментальна програма тренувальних занять відповідає основному напрямку в тренуванні для мезоморфів - різностороннє тренування, і призвела до достовірного збільшення м'язової, відносної м'язової та активної маси тіла $(p<0,05)$. У ході експерименту відбулося недостовірне зниження маси жирової тканини, відносної маси жирової тканини та середньої товщини підшкірно-жирових складок спортсменів групи «Б» ( $>>0,05)$.

Аналіз одержаних результатів свідчить про те, що застосування експериментальної програми тренувальних занять відповідає основному напрямку в тренуванні для ектоморфів і призвело до достовірного збільшення маси тіла, активної, м'язової та відносної м'язової маси тіла $(\mathrm{p}<0,05)$. У ході експерименту відбулося недостовірне зниження маси жирової тканини, відносної маси жирової тканини та середньої товщини підшкірно-жирових складок спортсменів групи «В» $(p>0,05)$. Це підтверджує, що

\section{Література}

1. Розенблюм Кристин А. Питание спортсменов / Кристин А. Розенблюм. - К. : Олимп. лит., 2005. - 535 с.

2. Мартиросов Э. Г. Технологии и методы определения состава тела человека / Э. Г. Мартиросов, Д. В. Николаев, С. Г. Руднев. - М. : Наука, 2006. - 248 с

3. Олешко В. Г. Силові види спорту / В. Г. Олешко. - К.: Олімп. л-ра, 1999. -288 c.

4. Основные понятия теории и методики обучения в тяжелой атлетике, гиревом спорте и атлетизме / под ред. В. Г. Олешко, П. М. Мироненко, А. Н. Янкевича. - К. : Наук. світ, 1990. - 20 с.

5. Платонов В. Н. Периодизация спортивной тренировки. Общая теория и ее практическое применение / В. Н. Платонов - К. : Олимп. лит., 2014. - 624 с.

6. Платонов В. Н. Система подготовки спортсменов в олимпийском спорте. Общая теория и ее практические приложения : учебник : в 2 кн. / В. Н. Платонов. - К. : Олимп. лит., 2004. - 800 с.

7. Пітенко С. Л. Морфологічні особливості спортсменів високої кваліфікації з різною будовою тіла / С. Л. Пітенко // Фізична культура і спорт у сучасному суспільстві: досвід, проблеми, рішення (у цикл Анохінських читань) : матеріали Міжнар. наук.-практ. конф. (К., 31 жовт., 2014 р.). - C. 142-149.

8. Уилмор Дж. Х. Физиология спорта : учебник : пер. с англ. / Дж. Х. Уилмор, Д. Л. Костилл. - К. : Олимп. лит., 2001. - 504 с.

9. Хоули Эдвард Т. Оздоровительный фитнес / Эдвард Т. Хоули, Б. Дон Френкс. - К. : Олимп. лит., 2000. - 367 с.

10. Физиологическое тестирование спортсмена высокой квалификации: пер с англ / Р. Д. Х. Бекус, Е. У. Банистер, К. Бушар, С. Дюлак. - К. : Олимп. лит., 1998. - 431 с.

sportmedkafedra@gmail.com експериментальна програма виявилася адекватною будові тіла даної групи спортсменів.

\section{Висновки.}

Урахування особливостей будови тіла спортсменів в експериментальних тренувальних програмах привело до позитивних змін показників, що вивчалися та виявилися адекватними для спортсменів всіх груп.

Аналіз одержаних результатів свідчить про те, що застосована контрольна програма тренувальних занять може використовуватись для зниження маси жирової тканини ендоморфрів.

Достовірне збільшення м'язової маси у мезоморфів $€$ підтвердженням того, що контрольна програма відповідає основному напрямку в тренуванні для мезоморорів та виявилася адекватною будові тіла даної групи спортсменів.

Однак незначне та недостовірне збільшення м'язової маси ендоморфів та ектоморфрів свідчить про те, що в цілому контрольна програма виявилася не адекватною будові тіла ендоморфів та ектоморфів.

\section{References}

1. Kristin A. Rozenblyum (2005). Pitanie sportsmenov [Feeding athletes]. Kiev: Olimpiyskaya literatura [in Russian].

2. Martirosov, E.G., Nikolaev, D.V., \& Rudnev, S.G. (2006). Tehnologii i metodyi opredeleniya sostava tela cheloveka [Technologies and methods for determining the composition of the human body]. Moscow: Nauka [in Russian].

3. Oleshko, V.G. (1999). Silovi vidi sportu [Power Sports]. Kiiv: Olimpiyska literatura [in Ukraine].

4. Oleshko, V.G., Mironenko, P.M., \& Yankevich, A.N. (Eds.) (1990). Osnovnyie ponyatiya teorii $i$ metodiki obucheniya $v$ tyazheloy atletike, girevom sporte $i$ atletizme [Basic concepts of theory and methods of training in weightlifting, weight-lifting and athleticism]. Kiev: Naukoviy svit [in Ukranian].

5. Platonov, V.N. (2014). Periodizatsiya sportivnoy trenirovki. Obschaya teoriya $i$ ee prakticheskoe primenenie [Periodization of sports training. General theory and its practical application]. Kiev: Olimpiyskaya literatura [in Russian].

6. Platonov, V.N. (2015). Sistema podgotovki sportsmenov $v$ olimpiyskom sporte. Obschaya teoriya i ee prakticheskie prilozheniya [The system of training athletes in the Olympic sport. General theory and its practical applications]. Kiev: Olimpiyskaya literatura [in Russian].

7. Pitenko, S.L. (2014). Morfologichni osoblyvosti sportsmeniv vysokoyi kvalifikaciyi z riznoyu budovoyu tila [Morphological features highly skilled athletes with different body constitution]. Proceedings from Physical culture and sport in modern society: experience, problems, solutions (in the cycle of Anokhin Readings): Mizhnarodna naukovo-praktychna konferentsiya (31 zhovtnya 2014 roku) - Materials of the International Scientific and Practical Conference. (pp. 142-149). Kyiv [in Ukranian].

8. Uilmor, Dzh.H., \& Kostill, D.L. (2001). Fiziologiya sporta [Physiology of sports]. Kiev: Olimpiyskaya literatura [in Russian].

9. Edvard T. Houli, \& B. Don Frenks (2000). Ozdorovitelnyiy fitnes [Wellness Fitness]. Kiev: Olimpiyskaya literatura [in Russian].

10. Bekus, R.D.H., Banister, E.U., Bushar, K., \& Dyulak, S. (1998). Fiziologicheskoe testirovanie sportsmena vyisokoy kvalifikatsii [Physiological testing of a highly qualified athlete]. Kiev: Olimpiyskaya literatura [in Russian].

Надійшла 14.03.2017 